\title{
Potential of Some Plant Extracts in Controlling Wheat Leaf Rust Caused by Puccinia triticina Eriks
}

\author{
Amal Ahmed Elkhwaga ${ }^{1}$, Abdelnaser A. Elzaawely ${ }^{2 *}$ Ibrahim Sobhy Draz ${ }^{1}$, \\ Abdelwahab A. Ismail ${ }^{1}$, Hassan M. El-Zahaby ${ }^{2}$ \\ ${ }^{1}$ Agricultural Research Centre, Plant Pathology Research Institute, Giza 12619, Egypt. \\ ${ }^{2}$ Department of Agricultural Botany, Faculty of Agriculture, Tanta University, Tanta, \\ 31527, Egypt.
}

\begin{abstract}
$\mathbf{L}$ EAF rust, caused by Puccinia triticina Eriks., is among the most common wheat rust diseases in Egypt causing major losses in the grain yield. The objective of this study was to evaluate the efficacy of water and $80 \%$-methanol extracts prepared from seven different plants (henna, blue gum, acalypha, chinaberry, pomegranate, basil, and lantana) in controlling the leaf-rust disease of wheat. In an in vitro experiment, all methanol extracts inhibited the germination of the fungus spores by more than $98 \%$, while water extracts were less effective. The methanol extracts of henna, lantana, acalypha, chinaberry, and pomegranate exhibited a $100 \%$-inhibition of spore germination. In addition, no significant differences were recorded between the methanol extracts of these five plants and the synthetic fungicide Fungshou. In a filed experiment, wheat plants were one- and two-time sprayed with henna, lantana, acalypha, chinaberry, and pomegranate water or methanol extracts. The results revealed that all plant extracts not only decreased the disease severity of the leaf rust, but also enhanced the grain yield components including spike weight, the 1000-kernel weight, and the test weight. Furthermore, the two-time spray application was more effective than the one-time spray. Our study indicated that water and methanol extracts of henna, lantana, acalypha, chinaberry, and pomegranate might be utilized for the control of wheat leaf-rust disease as a safe and environmentally friendly alternative to synthetic fungicides.
\end{abstract}

Keywords: Wheat leaf rust, Plant extracts, Biological control, Disease management.

\section{Introduction}

Wheat (Triticum aestivum L.) is one of the most important nutritive cereal crops in Egypt in terms of the planted area and crop production. The area cultivated with wheat in Egypt was estimated at 1.4 million ha (3.3 million Feddans) that produce 9.0 million tons of grains (FAOSTAT 2016). The Egyptian government aimed to fill the gap between the real production and the increasing consumption by raising the total wheat production via procedures, which lead to high yield. Leaf rust disease is considered the most common and widely distributed of the three rusts of wheat in Egypt and worldwide and has become more serious problems of wheat, causing great losses in grain yield (McIntosh et al. 1995; Mcvey et al. 2004; Huerta-Espino et al. 2011). Historically, rusts have been considered the major biotic production constraints in the world (Singh and Rajaram 1991). Wheat leaf rust is caused by the fungus Puccinia triticina Eriks. (Sym. P. rcondita Rob. Ex. Desm. f. sp. tritici Eriks and Henn), which attacks leaves in the highly susceptible varieties (Huerta-Espino et al. 2011). It causes severe losses in yield that could reach $50 \%$ in Egypt (Abdel-Hak et al. 1980). Injudicious use of synthetic fungicides for controlling plant diseases has ultimate negative effects on human and animal health and agro-ecosystem.

Plant extracts are among the biological control agents that directly affect the plant pathogens and can induce resistance in plants against phytopathogens (Mishra and Raja 1999). Recently, plant extracts have gained considerable attention as alternative options to synthetic fungicides and efforts have been made to utilize these extracts in the control strategies against plant diseases (Srivasata et al. 2011; Elsharkawy and El-Sawy 2015). It has been previously proven that plant extracts are effective control agents

*Corresponding author e-mail: elzaawely@agr.tanta.edu.eg

DOI: 10.21608/jenvbs.2018.4421.1031

(C)2017 National Information and Documentation Center (NIDOC) 
against a wide range of plant pathogens including fungal, bacterial and viral pathogens (Amadioha 2003; Bowers and Locke 2004; Sahayaraj et al. 2009). In addition, plant extracts or plant natural products are considered as systemic fungicides that have no side effects on human health or the environment (Singh 1994).

Therefore, the aim of the present study was to evaluate the efficacy of some plant extracts against the wheat leaf-rust disease in comparison with a synthetic fungicide.

\section{Materials and Methods}

The present investigation was carried out at the laboratory and the experimental farm of wheat disease division, Gemmeiza agricultural research station, agricultural research center, Egypt during 2015/2016 growing season.

\section{Plant material}

Dried henna leaves and pomegranate fruit peels were obtained from the local market. In addition, fresh disease-free leaves of five plant species were collected from the garden of the Gemmeiza agricultural research station. Samples were washed separately with tap water and were dried in an electric oven at $40^{\circ}$ for 4 days. The dried samples were kept at $-20^{\circ}$ until use. Information regarding the plant scientific names, English names and parts used are shown in Table 1.

\section{Preparation of plant extracts}

Ten $g$ dried powdered of each plant sample were separately extracted with distilled water or aqueous methanol $80 \%(3 \times 100)$ for $24 \mathrm{~h}$ at room temperature. The obtained extracts were separately collected, filtered and concentrated at $40^{\circ}$. Subsequently, a stock solution (100,000 ppm) of each extract was prepared by dissolving the dried crude extract in sterilized distilled water and kept in the refrigerator until use.

Collection of Puccinia triticina spores the causal fungus of wheat leaf rust disease

Spores of Puccinia triticina (the causal fungus of wheat leaf-rust disease) were collected from commercial wheat fields and the Egyptian Wheat Rust Trap Nurseries. The diseased samples included the infected leaves showing typical leaf rust symptoms and uredospores were morphologically and microscopically examined to make sure of the specifications of the causal agent following of Wiese (1982). The collected samples (rusted leaves) were left at room temperature for overnight to be dried off then the samples were kept in glassine envelopes $(8 \times 15 \mathrm{~cm})$ and stored in the refrigerator at $5^{\circ} \mathrm{C}$ until use.

\section{Effect of plant extracts on spore germination of $P$. triticina under laboratory conditions}

Seven plant extracts (Table 1) were tested for their inhibitory effect on spore germination of $P$. triticina. For each water or methanol extract, serial concentrations $(1000,1500,2500,3500 \mathrm{ppm})$ in Potato Dextrose Agar (PDA) were prepared, as well as, fungicide Fungshou $(0.075,0.75,1.0$ and $1.50 \mathrm{ppm})$. Five replicates of each treatment were used and inoculated with $1 \mathrm{ml}$ of urediniospores suspension $\left(5 \times 10^{4}\right.$ spores $\left.\mathrm{ml}^{-1}\right)$ of $P$. triticina in Petri dishes $(5 \mathrm{~cm}$ diameter) using distilled water as a negative control. All inoculated dishes were incubated at $20^{\circ}$ and microscopically examined to observe urediniospore germination $24 \mathrm{~h}$ after treatment. The percent of spore germination was calculated by the following formula:

$$
\mathrm{G} \text { percentage }=\mathrm{A} / \mathrm{B} \times 100
$$

TABLE 1. Plant samples used in the study.

\begin{tabular}{lcccc}
\hline Common name & Abbreviation & Scientific name & Family & Part used \\
\hline Henna & H & Lowsonia inermis & Lythraceae & Leaves \\
Acalypha & $\mathrm{A}$ & Acalypha wilkesiana & Euphorbiceac & Leaves \\
Bluegume & $\mathrm{B}$ & Eucalyptus globulus & Myrtaceae & Leaves \\
Chinaberry & $\mathrm{C}$ & Melia azedarach & Meliaceae & Leaves \\
Pomegranate & $\mathrm{P}$ & Punica granatum & Punicaceae & Fruit peel \\
Basil & $\mathrm{BS}$ & Ocimum basilicum & Lamiaceac & Leaves \\
Lantana & $\mathrm{L}$ & Lantana camara & verbenaceac & Leaves \\
\hline
\end{tabular}

Env. Biodiv. Soil Security Vol. 2 (2018) 
where: $\mathrm{G}=$ Percent of spore germination, $\mathrm{A}=$ Number of spores germinated and $B=$ Number of spores observed.

Inhibition percent of spore germination was calculated using the following formula (Shabana et al. 2017):

where: $\mathrm{C}=$ germination percent of spores in the negative control, $\mathrm{T}=$ germination percent of spores in the treatment.

Inhibition $\%=\frac{C-T}{C}^{\top} \times 100$

where $\mathrm{C}$ is the germination percentage of spores in the control, while $\mathrm{T}$ is the germination percentage of spores in the treatment.

\section{Control of wheat leaf rust by plant extracts under greenhouse}

This experiment was carried out at the experimental farm of Gemmeiza agricultural research station, Egypt using split plot design with three replicates to evaluate the ability of methanol or water extracts $(50 \mathrm{mg} / \mathrm{ml})$ as well as the fungicide Fungshou $(0.15 \mathrm{mg} / \mathrm{ml})$ to control the wheat leaf rust. The main plots were represented by one- and two-sprays for each treatment. The first spray was applied after the infection appearance and the second spray was applied after 15 days of the first one. The Sub plots were represented by the tested extracts. Grains of the susceptible wheat variety (Gemmiza7) were sown in experimental plots consisted of three rows with $3 \mathrm{~m}$ long and $30 \mathrm{~cm}$ apart received $8 \mathrm{~g}$ of grains/ row. All plots were surrounded by a spreader area with a highly susceptible wheat variety (Morocco). All cultural practices recommended in the commercial fields i.e. fertilization, irrigation and other management were applied. At the booting stage, the spreader plants were inoculated as previously mentioned according to Tervet and Cassell (1951). The infection types of wheat leaf rust used in disease assessment were adopted from Johnston and Browder (1966). Disease severity was estimated as infection percentage coverage of leaves with rust pustules using Modified Cobb's scale (Peterson et al. 1948). The efficacy percentage of treatment was determined according to the following equation adopted by Rewal and Jhooty (1985):

$$
\text { Efficacy } \%=\frac{C-T}{C} \times 100
$$

where $\mathrm{C}=$ infection $(\%) \stackrel{\mathrm{C}}{\text { in }}$ control, while $\mathrm{T}=$ infection $(\%)$ in treatment.

\section{HPLC analysis}

As extracts of acalypha and lantana exhibited the best results, they were analyzed by HPLC according to the method described by Kim et al. (2006). The analysis was carried out using Agilent Technologies 1100 series liquid chromatograph equipped with an autosampler and a diode-array detector. The analytical column was an Eclipse XDB-C18 (150 X $4.6 \mu \mathrm{m} ; 5 \mu \mathrm{m})$ with a C18 guard column (Phenomenex, Torrance, CA). The mobile phase consisted of acetonitrile (solvent A) and $2 \%$ acetic acid in water (v/v) (solvent B). The flow rate was kept at $0.8 \mathrm{ml} / \mathrm{min}$ for a total run time of $60 \mathrm{~min}$ and the gradient programme was as follows: $100 \% \mathrm{~B}$ to $85 \% \mathrm{~B}$ in $30 \mathrm{~min}, 85 \% \mathrm{~B}$ to $50 \% \mathrm{~B}$ in $20 \mathrm{~min}, 50 \% \mathrm{~B}$ to $0 \% \mathrm{~B}$ in $5 \mathrm{~min}$ and $0 \%$ $\mathrm{B}$ to $100 \% \mathrm{~B}$ in $5 \mathrm{~min}$. The injection volume was $50 \mu \mathrm{l}$ and peaks were monitored simultaneously at 280 and $320 \mathrm{~nm}$ for the benzoic acid and cinnamic acid derivatives, respectively as well as $360 \mathrm{~nm}$ for flavonoids. All samples were filtered through a $0.45 \mu \mathrm{m}$ Acrodisc syringe filter (Gelman Laboratory, MI) before injection. Peaks were identified by congruent retention times and UV spectra and compared with those of the standards.

\section{Statistical analysis}

The statistical analysis was done for data using CoStat software program by LSD method (Steel and Torrie 1980). Values of observed $\mathrm{IC}_{50}$

TABLE 2. Infection types of wheat leaf rust used in disease assessment.

\begin{tabular}{lll}
\hline Infection type & Host response & Symptoms \\
\hline Resistant & 0 Immune & No uredia or other macroscopic sign of infection \\
& 0 Nearly immune & No uredia, but hypersensitive necrotic or chlorotic flecks present \\
& 1 Very resistant & Small uredia surrounded by necrosis \\
& 2 Moderately resistant & Small to medium uredia surrounded by chlorosis or necrosis \\
\hline Susceptible & 3 Moderately susceptible & Medium-sized uredia that may be associated with chlorosis \\
& 4 Very susceptible & Large uredia without chlorosis or necrosis \\
\hline Mesotheic & X Heterogeneous & Random distribution of variable-sized uredia on a single leaf \\
\hline
\end{tabular}


for tested samples against spore leaf rust were calculated according to the linear relation between inhibitory probit and concentration logarithm.

\section{Results}

In vitro inhibition of the germination of $P$. triticina urediniospore

Urediniospore germination and appressorial formation are prerequisite direct penetration of the host surface. Therefore, a comparative study has been carried out to identify the effect of fungicide Fungshou (F), henna (H), bluegum (B), acalypha $(\mathrm{A})$, chinaberry $(\mathrm{C})$, pomegranate $(\mathrm{P})$, basil $(\mathrm{BS})$ and lantana (L) on the spore germination of Puccinia triticna. Except for B and BS extracts, all other water or methanol extracts reduced urediniospore germination of $P$. triticina at a different extent and the inhibition percentage was dose-dependent (Table 3). Fungshou fungicide completely inhibited $(100 \%)$ the urediniospore germination of $P$. triticina at a concentration of 1.5 ppm, while methanol extracts of $\mathrm{H}, \mathrm{A}$, and $\mathrm{L}$ gave a similar result at $3500 \mathrm{ppm}$ (Table 3).

The inhibitory concentration that needed to inhibit spore germination by $50 \%\left(\mathrm{IC}_{50}\right)$ for all treatments was estimated by probit analysis and presented in Table 4. Lower $\mathrm{IC}_{50}$ indicates higher inhibitory percentage. Methanol extracts prepared from $\mathrm{L}, \mathrm{A}$, and $\mathrm{H}$ exhibited lower $\mathrm{IC}_{50}$ values than other plant extracts, recorded 2020.81, 2030.31 and $2040.31 \mathrm{ppm}$, respectively (Table 4). In addition, $\mathrm{L}$ and $\mathrm{C}$ water extracts possessed strong inhibitory percentage with $\mathrm{IC}_{50}$ values 2048.08 and $2080.45 \mathrm{ppm}$ (Table 4). In comparison, the fungicide $\mathrm{F}$ was much stronger than the plant extracts exhibiting $\mathrm{IC}_{50}$ value $76.37 \mathrm{ppm}$.

Based on the above-mentioned results, extracts of $\mathrm{H}, \mathrm{A}, \mathrm{C}, \mathrm{P}$, and $\mathrm{L}$ were selected for field experiment to study their ability to reduce the disease incidence of wheat-leaf rust against the susceptible cv. Gemmeiza 7 during 2015/16 growing season at Gemmeiza Agricultural Research Station.

\section{Control of wheat leaf rust by plant extracts}

Results in Table 5 revealed that the application of either one or two foliar sprays of all the used botanicals showed high efficacy for reducing disease severity comparing with the untreated control. Data of two sprays seemed to be more effective than one spray. Among all plants, lantana water extracts were the most effective treatment with an efficacy 64.0 and $72.0 \%$ for the one-time and two-time sprays, respectively; whereas the lowest efficacy was recorded when plants treated with pomegranate water extracts ( 40.0 and $56.0 \%$, respectively). Furthermore, acalypha methanol extracts possessed the highest efficacy (60.0 and $72.0 \%$ ) for the one-time and two-time sprays, respectively; whilst the lowest one was found with chinaberry (40.0 and $56.0 \%$, respectively). The fungicide (F) with one and two sprays gave an efficacy 89.9 and $93.6 \%$, respectively.

TABLE 3. Effect of plant extracts and fungicide on spore germination of $P$. triticina.

\begin{tabular}{|c|c|c|c|c|c|c|c|c|c|}
\hline \multirow{3}{*}{ Treatments } & \multirow{3}{*}{ Extracts } & \multicolumn{4}{|c|}{ Germination \% } & \multicolumn{4}{|c|}{ Inhibition \% } \\
\hline & & \multicolumn{4}{|c|}{ Concentration (ppm) } & \multicolumn{4}{|c|}{ Concentration (ppm) } \\
\hline & & 1000 & 1500 & 2500 & 3500 & 1000 & 1500 & 2500 & 3500 \\
\hline \multirow{2}{*}{ Henna } & methanol & 100.0 & 70.0 & 40.0 & 0.0 & 0.0 & 30.0 & 60.0 & 100.0 \\
\hline & water & 100.0 & 80.0 & 50.0 & 10.0 & 0.0 & 20.0 & 50.0 & 90.0 \\
\hline \multirow{2}{*}{ Bluegume } & methanol & 100.0 & 90.0 & 80.0 & 60.0 & 0.0 & 10.0 & 20.0 & 40.0 \\
\hline & water & 100.0 & 100.0 & 90.0 & 80.0 & 0.0 & 0.0 & 10.0 & 20.0 \\
\hline \multirow{2}{*}{ Acalypha } & methanol & 100.0 & 70.0 & 40.0 & 0.0 & 0.0 & 30,0 & 60.0 & 100,0 \\
\hline & water & 100.0 & 90.0 & 70.0 & 20.0 & 0.0 & 10.0 & 30.0 & 80.0 \\
\hline \multirow{2}{*}{ Chinaberry } & methanol & 100.0 & 70.0 & 50.0 & 20.0 & 0.0 & 30.0 & 50.0 & 80.0 \\
\hline & water & 100.0 & 70.0 & 50.0 & 20.0 & 0.0 & 30.0 & 50.0 & 80.0 \\
\hline \multirow{2}{*}{ Pomegranate } & methanol & 100.0 & 90.0 & 50.0 & 20.0 & 0.0 & 10,0 & 50.0 & 80.0 \\
\hline & water & 100.0 & 90.0 & 60.0 & 30.0 & 0.0 & 10.0 & 40.0 & 70.0 \\
\hline \multirow{2}{*}{ Basil } & methanol & 100.0 & 100.0 & 90.0 & 80.0 & 0.0 & 0.0 & 10.0 & 20.0 \\
\hline & water & 100.0 & 100.0 & 90.0 & 80.0 & 0.0 & 0.0 & 10.0 & 20.0 \\
\hline \multirow{2}{*}{ Lantana } & methanol & 100.0 & 70.0 & 40.0 & 0.0 & 0.0 & 30.0 & 60.0 & 100.0 \\
\hline & water & 100.0 & 80.0 & 50.0 & 10.0 & 0.0 & 20.0 & 50.0 & 90.0 \\
\hline Fungshou & - & 70.0 & 40.0 & 30.0 & 0.0 & 30.0 & 60.0 & 70.0 & 100.0 \\
\hline Control & - & 100.0 & 100.0 & 100.0 & 100.0 & 0.0 & 0.0 & 0.0 & 0.0 \\
\hline
\end{tabular}

- Fungshou fungicide was used at concentrations of $0.075,0.75,1.0$ and $1.5 \mathrm{ppm}$.

- Values are means of five replicates.

Env. Biodiv. Soil Security Vol. 2 (2018) 
TABLE 4. Probit analysis of the tested plant extracts and fungicide.

\begin{tabular}{lcccccc}
\hline Treatments & Extracts & $\begin{array}{c}\mathbf{I C}_{\text {50 }} \\
(\mathbf{p p m})\end{array}$ & Lower & Upper & $\begin{array}{c}\text { Standard } \\
\text { error }\end{array}$ & $\begin{array}{c}\text { IC99 } \\
(\mathbf{p p m})\end{array}$ \\
\hline Henna & methanol & 2040.31 & 1894.17 & 2185.74 & 84.82 & 10637.7 \\
& water & 2517.47 & 2291.06 & 2785.15 & 120.41 & 6428.82 \\
Bluegume & methanol & 2978.53 & 2727.07 & 3334.92 & 146.087 & 10817.6 \\
& water & 3291.39 & 2938.60 & 3911.63 & 222.572 & 15631.5 \\
Acalypha & methanol & 2030.31 & 1894.17 & 2189.37 & 92.0052 & 5329.35 \\
Chinaberry & water & 2548.08 & 2246.98 & 2948.62 & 164.19 & 18260.4 \\
\multirow{2}{*}{ Pomegranate } & methanol & 2070.49 & 1910.08 & 2195.35 & 96.0075 & 18260.4 \\
& water & 2080.45 & 1946.98 & 2248.62 & 164.19 & 5411.15 \\
Basil & water & 2494.97 & 2301.19 & 2716.34 & 102.40 & 8380.73 \\
& methanol & 2672.37 & 2727.07 & 3334.92 & 146.09 & 10817.6 \\
Lantana & water & 3146.33 & 2871.45 & 356.93 & 134.062 & 11551.7 \\
Fungshou & methanol & 2020.81 & 1844.61 & 2182.35 & 72.0052 & 10021.5 \\
& water & 2048.08 & 1995.09 & 2448.53 & 111.079 & 5329.35 \\
& - & 76.37 & 13.96 & 417.81 & 101.59 & 2192.28 \\
\hline
\end{tabular}

TABLE 5. Efficacy of plant extracts and fungicide in controlling wheat leaf-rust under field conditions.

\begin{tabular}{lcccccccc}
\hline \multirow{2}{*}{ Treatments } & \multicolumn{4}{c}{ Disease severity (\%) } & \multicolumn{5}{c}{ Efficacy (\%) } \\
\cline { 2 - 10 } & WS1 & WS2 & MS1 & MS2 & WS1 & WS2 & MS1 & MS2 \\
\hline Henna & $30.0 \pm 3.33 \mathrm{bc}$ & $20.0 \pm 5.8 \mathrm{bc}$ & $35.0 \pm 3.33 \mathrm{~b}$ & $27.5 \pm 3.33 \mathrm{~b}$ & 52.0 & 68.0 & 44.0 & 56.0 \\
Acalypha & $32.5 \pm 3.33 \mathrm{~b}$ & $27.5 \pm 3.33 \mathrm{~b}$ & $25.0 \pm 3.33 \mathrm{c}$ & $17.5 \pm 3.33 \mathrm{c}$ & 48.0 & 56.0 & 60.0 & 72.0 \\
Chinaberry & $30.0 \pm 3.33 \mathrm{bc}$ & $22.5 \pm 3.33 \mathrm{bc}$ & $37.5 \pm 3.33 \mathrm{~b}$ & $27.5 \pm 3.33 \mathrm{~b}$ & 52.0 & 64.0 & 40.0 & 56.0 \\
Pomegranate & $37.5 \pm 3.33 \mathrm{~b}$ & $27.5 \pm 3.33 \mathrm{~b}$ & $30.0 \pm 3.33 \mathrm{bc}$ & $25.0 \pm 3.33 \mathrm{bc}$ & 40.0 & 56.0 & 52.0 & 60.0 \\
Lantana & $22.5 \pm 3.33 \mathrm{c}$ & $17.5 \pm 3.33 \mathrm{c}$ & $37.5 \pm 3.33 \mathrm{~b}$ & $27.5 \pm 3.33 \mathrm{~b}$ & 64.0 & 72.0 & 40.0 & 56.0 \\
Fungicide & $6.3 \pm 1.67 \mathrm{~d}$ & $4.0 \pm 0.67 \mathrm{~d}$ & $6.3 \pm 1.67 \mathrm{~d}$ & $4.0 \pm 0.67 \mathrm{~d}$ & 89.9 & 93.6 & 89.9 & 93.6 \\
Control & & & \multicolumn{7}{c}{$62.5 \pm 3.33 \mathrm{a}$} & & & & \\
LSD 0.05 & 8.24 & 7.81 & 8.39 & 9.73 & & & & \\
\hline
\end{tabular}

- WS1: Water extract with one-time spray, WS2: Water extract with two-time spray, MS1: Methanol extract with one-time spray, MS2: Methanol extract with two-time spray.

- Means values in each column followed by the same letter are not significantly different ( $\mathrm{P} \leq 0.05)$.

Efficacy of plant extracts on wheat yield components

Table 6 shows the effect of foliar spraying of plant extracts and fungicide on wheat yield components infected by leaf rust. The reflex of the efficacy of treatments on grain yield components revealed that all the used plant extracts and fungicide improved wheat yield components including spike weight, 1000-kernel weight and test weight under one- or two-spray applications. Lantana water extract and acalypha methanol extract, as well as the fungicide Fungshou, exhibited the highest values for the studied yield components in comparison with other plant extracts or control (Table 6). In addition, the two- spray application was the most effective with significant differences.

\section{HPLC analysis}

HPLC analysis indicated that acalypha and lantana extracts contain a wide array of phenolic compounds and flavonoids (Table 7). Both methanolic extracts prepared from acalypha and lantana leaves contain the flavonoid rutin as a predominant phenolic (Table 7). Furthermore, gallic acid was the major phenolic compound in acalypha water extract, while lantana water extract contains rosmarinic acid as a major compound (Table 7). 
TABLE 6. Efficacy of plant extracts on wheat yield components.

\begin{tabular}{|c|c|c|c|c|c|c|c|c|c|c|c|c|}
\hline \multirow{2}{*}{ Ir. } & \multicolumn{4}{|c|}{ Spilie weight (g) } & \multicolumn{4}{|c|}{ 1000-Kernel wetight (g) } & \multicolumn{4}{|c|}{ Test weight (g) } \\
\hline & W\$1 & WS2 & MS1 & MS2 & WS1 & W\$2 & MS1 & MS2 & WS1 & WS2 & MS1 & M.S2 \\
\hline $\bar{H}$ & $3.53 \pm 0.0 \mathrm{lb}$ & $4.19 \pm 0.010$ & $3.25 \pm 002 \mathrm{dd}$ & $3.96 \pm 0,012 \mathrm{c}$ & $51.38+0.012 a$ & $52.1 \pm 0.012 c$ & $4588 \pm 0.12 \mathrm{~d}$ & $49.75 \pm 0.12 \mathrm{ed}$ & $696.73 \pm 0.01 \mathrm{ab}$ & $711.9+0.1 \mathrm{~b}$ & $690.83 \div 0.1 \mathrm{c}$ & $6983+0.10$ \\
\hline$A$ & $3.17 \pm 001 \mathrm{ld}$ & $403 \pm 0.01 \mathrm{e}$ & $3.43 \pm 0.02 \mathrm{~b}$ & $4.26 \pm 0012 \mathrm{~b}$ & $4608 \pm 1.15 \mathrm{c}$ & $51.35+0.12 c$ & $5189 \pm 0.12 a$ & $52.93 \div 0.12 a$ & $68793 \pm 0.01 \mathrm{~d}$ & $696.7 \pm 0.1 \mathrm{~d}$ & $699 \pm 0.1 \mathrm{a}$ & $709.8 \pm 0.1 \mathrm{la}$ \\
\hline C & $3.44 \pm 0.01 \mathrm{c}$ & $4.16 \pm 0.01 \mathrm{ed}$ & $3.20 \pm 0.020$ & $3.43 \pm 0.015 \mathrm{f}$ & $50.01 \pm 0.0126$ & $52 \pm 1.15 \mathrm{c}$ & $44.1 \pm 0.12 \mathrm{~d}$ & $49.18 \pm 0.12 \mathrm{~d}$ & $694.6 \pm 1.15 \mathrm{c}$ & $696.5 \pm 0.1 \mathrm{~d}$ & $683.8 \pm 0.10$ & $691 \pm 1.2 \mathrm{~d}$ \\
\hline $\mathrm{P}$ & $3.16 \pm 0.01 \mathrm{~d}$ & $4.14 \pm 0.01 d$ & $3.27 \pm 0.01 \mathrm{c}$ & $4.21 \pm 0.012 \mathrm{c}$ & $40.05 \pm 0.12 \mathrm{~d}$ & $45.95 \pm 0.12 \mathrm{~d}$ & $50.35 \div 0.12 b$ & $52.1 \pm 0.66 \mathrm{ab}$ & $688.6 \pm 0.012 \mathrm{~d}$ & $696.2 \pm 0.1 \mathrm{e}$ & $698.1 \pm 1.2 \mathrm{a}$ & $704.9 \pm 1.2 \mathrm{~b}$ \\
\hline L & $3.65 \pm 0.01 \mathrm{a}$ & $4.51 \pm 0.01 \mathrm{la}$ & $3.23 \pm 001$ de & $4.02 \pm 0012 \mathrm{~d}$ & $51.84 \pm 0.012 \mathrm{a}$ & $53.5 \pm 0012 \pi$ & $47.34 \pm 1.15 \mathrm{c}$ & $5055+0.12 \mathrm{c}$ & $698.8 \pm 0.18 a$ & $719,9 \pm 0.2 \mathrm{a}$ & $688.8+0.2 \mathrm{~d}$ & $697 \pm 0.2 \mathrm{c}$ \\
\hline F & $3.65 \pm 0.00 \mathrm{a}$ & $4,33 \pm 0,01 \mathrm{a}$ & $3.65 \pm 0.00 \mathrm{a}$ & $4,33 \pm 0,01 \mathrm{a}$ & $51.84 \pm 1.15 a$ & $54,95 \pm 1.15 b$ & $51.84 \pm 1.15 \mathrm{a}$ & $54.95 \pm 1.15 \mathrm{~b}$ & $694.83 \pm 0.0 \mathrm{tx}$ & $699,9 \pm 0.0 \mathrm{c}$ & $694.83 \pm 0.0 \mathrm{bc}$ & $6999 \pm 0.0 \mathrm{c}$ \\
\hline Ca. & \multicolumn{4}{|c|}{$3.03+0.012 \mathrm{f}$} & \multicolumn{4}{|c|}{$37.53 \pm 1.15 f$} & \multicolumn{4}{|c|}{$6.99 .81+0.09 \mathrm{e}$} \\
\hline LSD C.05 & 0.03 & 0.04 & 0.19 & 0.04 & 1.05 & 1.16 & 1.36 & 0.87 & 2.15 & 1.74 & 1.28 & 4.39 \\
\hline
\end{tabular}

- Tr.: treatments, H: henna, A: acalypha, C; chinaberry, P: pomegranate, L; lantana, F: fungicide Fungshou, Co:; control, WS1: Water extract with one-time spray, WS2: Water extract with two-time spray, MS1: Methanol extract with one-time spray, MS2: Methanol extract with twotime spray.

- Means values in each column followed by the same letter are not significantly different $(\mathrm{P} \leq 0.05)$.

TABLE 7. Phenolic profile $(\mu \mathrm{g} / \mathrm{ml})$ of acalypha and lantana water and methanol extracts by HPLC analysis.

\begin{tabular}{lccccc} 
& \multicolumn{2}{c}{ Acalypha extracts } & \multicolumn{2}{c}{ Lantana extracts } \\
\cline { 2 - 6 } & $\begin{array}{c}\text { R.t. } \\
\text { (min) }\end{array}$ & Methanol & Water & Methanol & Water \\
\hline Gallic acid & 4.4 & 1.05 & 96.76 & ND & 0.71 \\
Protocatechuic acid & 7.4 & 1.68 & 1.22 & ND & ND \\
p-Hydroxybenzoic acid & 10.7 & 6.50 & 3.30 & 2.98 & ND \\
Gentisic acid & 11.5 & 1.72 & ND & 3.25 & ND \\
Cateachin & 12.2 & 5.94 & ND & ND & 8.13 \\
Chlorogenic acid & 13.2 & 2.23 & ND & ND & ND \\
Ferulic acid & 25.8 & ND & ND & ND & 0.56 \\
Sinapic acid & 27.5 & ND & ND & ND & 1.38 \\
p-Coumaric acid & 30.2 & 0.59 & ND & ND & ND \\
Rutin & 32.8 & 56.57 & 0.80 & 183.79 & 1.74 \\
Naringinin & 34.7 & ND & 2.97 & 3.47 & ND \\
Apigenin-7-glucoside & 36.3 & ND & ND & 2.76 & 2.43 \\
Rosmarinic acid & 37.5 & ND & ND & 1.91 & $\mathbf{1 5 . 3 8}$ \\
Kaempferol & 48.6 & ND & ND & ND & 3.98 \\
\hline
\end{tabular}

\section{Discussion}

Although synthetic fungicides have ultimate negative effects on human and animal health as well as agro-ecosystem, they have often been used for controlling high incidence of plant diseases such as wheat leaf-rust (Jarvis 1988). Eco-friendly control of plant diseases including plant extracts, which act directly on the plant pathogens or indirectly by inducing resistance in plants, have gained considerable attention as alternative means to synthetic fungicides (Mishra and Raja 1999). Using plant extracts in the control of wheat rusts is a modern, advanced and risk-free alternative method of rust management (Jarvis 1988). Several plant extracts are known to play an important role in the management of plant diseases (Ayoub and Niazi 2001; Joseph 2008; Sowjanya and Manohara 2012; Dey et al. 2013; Elsharkawy and El-Sawy 2015).

Env. Biodiv. Soil Security Vol. 2 (2018)
In the present study, water and methanol extracts of the tested plants (henna, acalypha, chinaberry, pomegranate, and lantana) proved to have high efficacy in inhibiting spore germination of $P$. triticina (the causal agent of wheat leaf-rust disease) under the laboratory or field conditions. Among these plants, acalypha methanol extract and lantana water extract possessed the highest control ability, as well as, increased the wheat yield components.

Boughalleb et al. (2005) reported that lantana stem and flower extracts showed a strong inhibitory effect against Alternaria solani, Botrytis cinerea, Fusarium solani f. sp. Cucurbitae, F. oxysporum $\mathrm{f}$. sp. Niveum, Pythium ultimum, Rhizoctonia solani and verticillium dahlia. In addition, Dabur et al. (2007) found that lantana water extracts exhibited good activity against several bacteria. Methanol leaf extract of lantana showed broad 
antifungal activity against Aspergillus flavus and $A$. niger (Fayaz et al. 2017). Aqueous and methanolic leaf extracts of lantana showed significant inhibition against Colletorichum falcatum (the causal fungi of sugarcane red-rot disease) under in vitro conditions (Sreeramulu et al. 2017). The water and ethanol extracts of acalypha leaf inhibited the growth of standard and local strains of bacteria and fungi including Staphylococcus aureus, Trichophyton rubrum, Trichophyton mentagrophytes, Candida albicans and Aspergillus flavus (Alade and Irobi 1993). The methanolic extract of acalypha totally inhibited Aspergillus flavus and A. fumigatus, while the water extract had varying inhibitory effects (Ezekiel et al. 2009). Acalypha and lantana leaf extracts inhibited the mycelial growth, sporulation and spore germination of Alternaria helianthi and can be used to manage this fungus under field condition (Devi et al. 2013).

\section{Conclusions}

In this study, seven plant extracts were found to be effective in reducing the spore germination of $P$. triticina (the causal agent of wheat leaf-rust disease) under the laboratory conditions. In a field experiment, water and methanol extracts of five plants (henna, acalypha, chinaberry, pomegranate, and lantana) along with the fungicide Fungshou possessed high efficacy in controlling the wheat leaf-rust disease. Among these plants, acalypha methanol extract and lantana water extract showed the highest control ability. HPLC analysis indicated the presence of various phenolic compounds in particular rutin in methanolic extracts of acalypha and lantana, gallic acid in acalypha water extract and rosmarinic acid in lantana water extract. Further studies on isolation, chemical elucidation and phytotoxicity of the active constituents in both extracts are needed before the possible use of these extracts in control strategies of this fungus.

\section{References}

Abdel-Hak, T. M., El-Sherif, N. A., Bassiony, A.A., Shafik, I. I. and El-Douadi, Y. (1980) Control of wheat leaf rust by systemic fungicides. In: Proceedings of the $5^{\text {th }}$ European and Mediterranean cereal rusts conference. Bari, Italy. 255-266.

Alade, P. I. and Irobi, O. N. (1993) Antimicrobial activities of crude leaf extracts of Acalypha wilkesiana. Journal of Ethnopharmacology, 39, 171-174.
Amadioha, A. C. (2003) Evaluation of some extract against Colletotrichum lindemuthianum on cowpea. Acta Phytopathologica et Entomologica Hungarica, 38, 259-265.

Ayoub M. and Niazi, A. U. (2001) Control of wheat rust by leaves extract of poisonous phanergamic plants. Journal Biological Science, 1, 490-491.

Boughalleb, N., Débbabi, N., Ben Jannet, H., Mighri, Z. and El Mahjoub, M. (2005) Antifungal activity of volatile components extracted from leaves, stems and flowers of four plants growing in Tunisia. Phytopathologia Mediterranea, 44, 307-312.

Bowers, J. H. and Locke, J. C. (2004) Effect of formulated plant extracts and oils on population density of Phytophthora nicotianae in soil and control of Phytophthora blight in greenhouse. Plant Diseases, 88, 11-16.

Dabur, R., Gupta, A., Mandal, T. K., Singh, D. D., Bajpai, V., Gurav, A. M. and Lavekar, G. S. (2007) Antimicrobial activity of some Indian medicinal plants. African Journal of Traditional, Complementary and Alternative Medicines, 4, 313 318.

Devi, P. A., Mohan, S. and Thiribhuvanamala, G. (2013) Antifungal activity of plant extracts against by Alternaria helianthi. Journal of Biopesticides, $\mathbf{6}$, 231-236.

Dey, U., Harlapur, S. I., Dhutraj, D. N., Suryawanshi, A. P., Jagtap, J. P., Apet, K. T., Badgujar, S. L., Gholve, V. M., Kamble, H. N., Kuldhar, D. P. and Wagh, S. S. (2013) Effect of fungicides, botanicals, bioagents and Indigenous Technology Knowledge (ITKs) on germination of urediniospores of Puccinia sorghi in vitro. African Journal of Agricultural Research, 8 , 4960-4971.

Elsharkawy, M. M. and El-Sawy, M. M. (2015) Control of bean common mosaic virus by plant extracts in bean plants. International Journal of Pest Management, 61, 54-59.

Ezekiel, C. N., Anokwuru, C. P., Nsofor, E., Odusanya, O. A. and Adebanjo, O. (2009) Antimicrobial activity of the methanolic and crude alkaloid extracts of Acalypha wilkesiana cv. macafeeana copper leaf. Research Journal of Microbiology, 4, 269-277.

FAOSTAT. (2016) Food and Agriculture Organization of the United Nations, FAOSTAT Agriculture Data. http://www.fao.org/faostat/en/\#data/QC (accessed July 5, 2018).

Env. Biodiv. Soil Security Vol. 2 (2018) 
Fayaz, M., Bhat, M. H., Fayaz, M., Kumar, A. and Jain, A. K. (2017) Antifungal activity of Lantana camara L. leaf extracts in different solvents against some pathogenic fungal strains. Pharmacologia, 8 , 105-112.

Huerta-Espino, J., Singh, R. P., German, S., McCallum, B. D., Park, R. F., Chen, W. Q., Bhardwaj, S. C. and Goyeau, H. (2011) Global status of wheat leaf rust caused by Puccinia triticina. Euphytica, 179, 143-160.

Jarvis W. (1988) Fusarium crown rot of tomatoes. Phytoprotection, 69, 49-64.

Johnston, C. O. and Browder, L. E. (1966) Seventh revision of the international register of physiologic races of Puccinia recondita f.sp. tritici. Plant Disease Reporter, 50, 756-760.

Joseph, B., Darand, M. A. and Kumar, V. (2008) Bioefficacy of plant extracts to control Fusarium solani f. sp. melangenae incitant of brinjal wilt. Global Journal of Biotechnology and Biochemistry, 3, 56-59.

Kim, K. H., Tsao, R., Yang, R. and Cui, S. W. (2006) Phenolic acid profiles and antioxidant activities of wheat bran extracts and the effect of hydrolysis conditions. Food Chemistry, 95, 466-473.

McIntosh, R. A., Wellings, C. R. and Park, R. F. (1995) Wheat rusts: an atlas of resistance genes Csiro Publishing.

McVey, D. V., Nazim, M., Leonard, K. J. and Long, D. L. (2004) Patterns of virulence diversity in Puccinia triticina on wheat in Egypt and the United States in 1998-2000. Plant Disease, 88, 271-279.

Mishra, S. K. and Raja, R. (1999) Systemic acquired resistance: a review. Annual of Agricultural Research, 20, 249-59.

Peterson, R. F., Campbell, A. B. and Hannah, A. E. (1948) A diagrammatic scale for estimating rust intensity on leaves and stems of cereals. Canadian Journal of Research, 26, 496-500.

Rewal, H. S. and Jhooty, J. S. (1985) Differential response of wheat varieties to systemic fungitoxicants applied to Ustilago tritici (Pers.). Rostr. Indian Journal of Agricultural Sciences, 55, 548-9.

Sahayaraj, K., Borgio, J. F. and Raju, G. (2009). Antifungal activity of three fern extracts on causative agents of groundnut early leaf spot and rust diseases. Journal of Plant Protection Research,

Env. Biodiv. Soil Security Vol. 2 (2018)
49, 141-144.

Schneider, S. and Ullrich, W.R. (1994) Differential induction of resistance and enhanced enzyme activities in cucumber and tobacco caused by treatment with various abiotic and biotic inducers. Physiology and Molecular Plant Pathology, 45: 291-304.

Shabana, Y. M., Abdalla, M. E., Shahin, A. A., ElSawy, M. M., Draz, I. S. and Youssif, A. W. (2017) Efficacy of plant extracts in controlling wheat leaf rust disease caused by Puccinia triticina. Egyptian Journal of Basic and Applied Sciences, 4, 67-73.

Singh, D. C. (1994) Scope of medicinal and aromatic plants in pest management. International symposium, allelopathy in sustainable agriculture, forestry and environment. New Delhi, Pp. 68.

Singh, R. P. and Rajaram, S. (1991) Resistance to Puccinia recondita f. sp. tritici in 50 Mexican bread wheat cultivars. Crop Science, 31, 1472-1479.

Sowjanya, N. and Manohara, C. (2012) Effect of plant extracts on the growth of Microsorum gypseum. Journal of Phytology, 4, 41-44.

Sreeramulu, A., Arunakumari, M. and Reddy, P. L. N. (2017) Antifungal Activity of wild sage (Lantana camara) against Colletotrichum falcatum. International Journal of Current Microbiology and Applied Sciences, 6, 847-1852.

Srivasata, S., Singh, V. P., Kumar, R., Srivasata, M., Sinha, A. and Simon, S. (2011) In vitro evaluation of Carbendazim 50\% WP, antagonists and botanicals against Fusarium oxysporum $\mathrm{f}$. sp. psidii associated with rhizosphere soil of guava. Asian Journal of Plant Pathology, 5, 46-53.

Steel, R. G. D. and Torrie, J. H. (1980) Principles and Procedures of Statistics. Second ed. Mc Graw Hil Book Company, New York.

Tervet, I. W. and Cassell, R. C. (1951) The use of cyclone separation in race identification of cereal rusts. Phytopathology, 41, 286-290.

Wiese, M. V. (1982) Compendium of Wheat Diseases. American Phytopathological Society, St. Paul, Minnesota, USA, Pp. 106.

(Received 11/7/2018; accepted 9/9/2018) 